\title{
PRESENT VERBS AND THEIR CONTEXTS IN BILINGUAL ORAL NARRATIVES
}

\author{
Liina Tammekänd \\ University of Tartu
}

\begin{abstract}
The paper discusses the use of present verbs in ten Estonian-Võru narrative pairs. The research questions are: which narrative tenses with which roles are used in Estonian and Võru narratives; in which narrative parts can present verbs be found; and which present contexts are used in the Võru narratives when compared to the Estonian narratives. It could be concluded that the deictic past, the deictic present and the conversational historical present are used in eight different contexts. These are the introduction, the conclusion, reporting verbs, the asides (universal truths, descriptions of the present situation caused by past events and comments to the listener without the direct address), addresses to the listener, the future meaning, the conversational historical present switch and the indirect speech. In the Vorru narratives, narrative events were conveyed using more preterite verbs when compared to the Estonian narratives, where descriptions of narrative events contained more present verbs.
\end{abstract}

Keywords: bilingual oral narrative, narrative tenses, conversational historical present, Estonian, Võru

DOI: http://dx.doi.org/10.12697/jeful.2015.6.3.09

\section{Introduction}

The default tense for a past narrative is usually the past, as the events which the story is based on have already happened in their entirety before narrating time (Fludernik 2009). However, there are some examples of present tense use in narrations (for example sport reports in Fludernik 2009) in case of which the events which the narration is based on are happening at the same time with narrating (ibid.). In stories embedded in everyday conversations, where interlocutors illustrate their viewpoints or recount what has happened to them (conversational narratives in Wolfson 1978 and 1979), past verbs can alternate with present verbs (Fludernik 2009). The aim of the present contribution is to discuss the use of present and past verbs in bilingual oral narratives about past events. The verbs of ten Estonian-Võru narrative pairs are studied. The 
research questions are as follows: 1 . Which narrative tenses are used in the Estonian-Võru narratives and what roles do they fulfil? 2. In which contexts can present verbs be found? 3. Which present contexts are used in the Vorru narratives when compared to the Estonian narratives?

The contribution is divided into four sections. The first section gives an overview of Estonian and Võru tense systems, discusses tense forms used in narratives and introduces the concept of conversational historical present. The second section describes the informants, the method and the subject matter. The third part discusses the use and roles of grammatical and narrative tenses in the narratives, and present contexts. Then the conclusion follows.

\section{Time and tense}

\subsection{Time and tense in Estonian and Võru}

Estonian and Vorru tense systems and their relationship to time are similar. Morphologically, there are only the present and the preterite in Estonian (EKG I: 237). The present verb is unmarked and there is no future verb (EKG II: 32, Erelt 2013: 91). For expressing future events, the present verb and other means, like time expressions and constructs (hakkama and saama) are used (Erelt 2013: 100-103). The present verb is also used to express the indefinite time (EKG II: 34). Therefore, the present verb expresses the following time references: 1 . an imperfect present action or event; 2 . a perfect or imperfect future action or event; 3. a possible future action or event, the beginnings of which are in the present (EKG II: 32); 4. the indefinite tense (EKG II: 32; Erelt 2013: 100-104).

There are four morphological past verbs: the preterite, the perfect, the pluperfect for the indicative and the indefinite past for the conditional, the quotative and the jussive (EKG I: 237-242). The preterite verb expresses a past action or event that is not related to the present in any way. The perfect verb joins a past action or event and the present situation. The pluperfect expresses an action or event that happened before another action or event in the past (ibid.). The indefinite past verb expresses a past action or event in all moods except the indicative (EKG I: 237-242). 


\subsection{Narrative tenses}

In fictional narratives, three different temporal planes meet. Interaction between narrative time (when the imaginary or real events occur), narrating time (when the narrator perpetuates the narrative events) and reading time (Genette 1972) makes it difficult to set one deictic centre (or the focal reference point in Fludernik 2009). It is because the deictic centres of the narrator and the reader often do not coincide, which means that the narrator's present is not the reader's present. So the narrator and the reader meet "in the narrative", where the common deictic point is created. This is also the reason why the past tense chosen to convey the events of the past narrative often does not indicate the specific time in the past but marks the distance of the events. The issue of deictic centres is somewhat simpler in the case of narratives embedded in everyday conversations. As the narrator and the listener share the same space and time, they also share the deictic centre in narrating time. (Fludernik 2009) However, in both described cases the choice of the grammatical tense might not be logically related to the actual time of events which the narrative is based on.

For the present discussion, it is important to differentiate between the grammatical tense and the narrative tense. The grammatical tense is a verbal/grammatical category that indicates "the relationship between the form of the verb and the time reference of an event or action" (Carter and McCarthy 2006: 926). The narrative tense is a specific use of the grammatical tense, it fulfils different roles and can be found in different narrative contexts. According to their contexts and functions, narrative tenses are dubbed the narrative past, the epic past and the narrative present, which has three further subgroups - the epic present, the deictic present and the historical present (see Table 1).

1. The narrative past is the default tense for describing past events. It indicates either real past (as used in historical non-fiction books), unspecified past or future (as used in science fiction and utopias) (Fludernik 2003 and 2009).

2. The epic past highlights the fact that the reader is dealing with a narrative. Using the epic past, the exact place and time of the events of the narrative are left in the background and therefore the reader/ listener perceives the past as present. The epic past is used mostly in third person narratives (for example in epics) (Hamburger 2011); however, Fludernik (2009) claims that the use of the epic past is rare. 
Table 1. Narrative tenses (Fludernik 2003, Hamburger 2011, and Jahn 2005)

\begin{tabular}{l|l} 
1. narrative past & \\
\hline 2. epic past & \\
\hline 3. narrative present & a) epic present \\
\hline & b) deictic present (also generic or gnomic present) \\
\hline & c) historical present (also dramatic present)
\end{tabular}

3. The narrative present is used instead of a narrative past to narrate past events. It has three roles.

a) The epic present is sometimes used instead of the past tense in third person narratives (reflector mode in Fludernik 2003). It is not a deictic present as the purpose of this particular present is to describe the main character's mind and highlight the changes it is undergoing (Fludernik 2003).

b) The deictic present (henceforth the DP) signals the deictic shift from narrating time to narrative time. Using the DP, the narrator communicates with the reader/listener, comments on the story and gives evaluations to the events of the narrative (Schriffin 1981). The deictic present might also be used to express general truths without any time reference (Jahn 2005), in which case it is dubbed the generic or gnomic present.

c) The historical present (also the dramatic present) is used in larger narrative blocks intermittently with the narrative past (Fludernik 2009). The historical present highlights narrative junctures, marks episode beginnings in oral narratives (Fudernik 2003), conveys the sense of immediacy or marks narrative climaxes (Jahn 2005). Traditional approaches (for example Carter and McCarthy 2006) describe the historical present as a stylistic device that is used to make the narrative more immediate and to leave the audience with an impression like the narrator relives the events, the events are happening concurrently with the narration, or the audience witnesses the events which the narrative is based on. Wolfson $(1978,1979$, and 1989) and Schriffin (1981) find that in case of oral narratives it is more suitable to discuss the conversational historical present (henceforth the CHP) instead of the historical, or dramatic, present. 


\subsection{Conversational Historical Present}

Wolfson (1978 and 1979) claims that the traditional roles of the historical present do not explain all functions of the present tenses in oral narratives. She asks if the purpose of the historical present is bringing the narrative closer to the audience and "dramatising" it, then why is so much important information still in the past tense. To explain this phenomenon, she renames the historical present in oral narratives and calls it the conversational historical present. Research (SilvaCorvalán 1983, Fludernik 1991, Sakita 2002, Nara 2011, and Bonilla 2011) allows to claim that the (C)HP exists in different languages. It is possible to point out the following features of the CHP:

1. In the conversational narrative, it alternates with the past tense.

2. It is interchangeable with the past tense. Not all verbs that could be in the CHP are in the CHP but in the past instead.

3. The CHP does not have a semantic meaning. The switch from the CHP to the past to the CHP or vice versa is important.

4. Use of the CHP is not obligatory in conversational narratives.

The past-CHP-past (or CHP-past-CHP) switch structures the narrative and marks the episodes: verbs that belong to the same episode are usually in the same tense. (Wolfson 1979 and Schriffin 1981)

As mentioned above, the CHP is not obligatory in conversational narratives. According to Wolfson (1978), the CHP is a "pragmatic, discourse and sociolinguistic device" that is used when the narrator perceives the listener (age, status, gender, the interpretation of the narrative) close to her. The CHP occurs seldom in a formal context (ibid.).

\section{Informants, method and subject matter}

Ten informants, five males and five females, participated in the present study. Five informants belong to the older generation (50-60 years) and five informants belong to the younger generation (30-40 years). L1 of nine of them is either Estonian or Võru. One of the informants did not want to disclose his L1. L1 of five informants is Võru. Two informants acquired Estonian and Võru simultaneously. All informants have strong connections to the city: they either live or study there. All informants have a secondary education and the majority of them have also a university diploma. 
The informants were asked to retell a memorable past event both in Estonian and in Võru, hence producing a bilingual narrative pair. The informants could choose the language of the first session themselves. There was at least a two-week pause between the two sessions. The narratives were recorded and transcribed. For the present study, the present and past verbs in the narrative pairs were counted and their frequency and contexts of occurrence analysed.

After content and thematic analysis of the narrative pairs, it appeared that the narratives fall under two main types according to their subject. Six informants told a story about a single memorable past event featuring more characters in addition to the narrator. The characters interact with each other and these interactions are conveyed in the indirect speech. This type of story is of short (250-350 words) or of medium (500600 words) length. The events which the story is based on happened in rather a distant past, either in childhood or in adolescence. Three informants told a story about an important transformative experience, like a near-death experience. This story does not include any characters or they are in the background and are mentioned only superficially. Interaction between the characters is missing or subdued. Many mental process and perception verbs are used (e.g. think, know, perceive, see) that are followed by explanation, reflection, general truths and evaluation. This type of story is lengthy (some of them over 1000 words). One informant told a story that is a mixture of the previously described stories.

\section{Present in the narrative pairs}

Table 2 gives an overview of the use of grammatical tenses in relation to the narrative length. In the Vorru narratives, there are $21 \%$ more verbs. This can partly be explained by the fact that the Voru narrative is $14 \%$ longer than the Estonian narrative, which is because of few very lengthy narratives. 
Table 2. Tense use in the narratives

\begin{tabular}{|c|c|c|c|c|c|c|c|c|c|c|}
\hline \multirow{2}{*}{$\begin{array}{c}\text { in- } \\
\text { for- } \\
\text { mants }\end{array}$} & \multicolumn{5}{|c|}{ Estonian } & \multicolumn{5}{|c|}{ Võru } \\
\hline & words & $\begin{array}{l}\text { pre- } \\
\text { sent }\end{array}$ & past & perf & $\begin{array}{l}\text { plu- } \\
\text { perf }\end{array}$ & words & $\begin{array}{l}\text { pre- } \\
\text { sent }\end{array}$ & past & perf & $\begin{array}{l}\text { plu- } \\
\text { perf }\end{array}$ \\
\hline $\mathrm{F} 1$ & 607 & 7 & 83 & 1 & 1 & 931 & 47 & 111 & 0 & 1 \\
\hline F2 & 553 & 39 & 45 & 1 & 0 & 438 & 19 & 46 & 1 & 0 \\
\hline F3 & 954 & 54 & 81 & 9 & 3 & 1698 & 87 & 161 & 1 & 8 \\
\hline $\mathrm{F} 4$ & 438 & 26 & 49 & 0 & 0 & 340 & 8 & 57 & 0 & 0 \\
\hline F5 & 610 & 21 & 74 & 0 & 0 & 716 & 41 & 95 & 0 & 0 \\
\hline M1 & 1324 & 41 & 154 & 2 & 11 & 1611 & 68 & 166 & 4 & 11 \\
\hline M2 & 386 & 30 & 33 & 0 & 0 & 356 & 6 & 60 & 0 & 0 \\
\hline M3 & 466 & 26 & 39 & 3 & 0 & 238 & 13 & 21 & 0 & 0 \\
\hline M4 & 692 & 15 & 62 & 2 & 0 & 755 & 28 & 59 & 4 & 0 \\
\hline M5 & 496 & 10 & 37 & 1 & 4 & 524 & 22 & 51 & 2 & 1 \\
\hline
\end{tabular}

Seven informants use perfect verbs in Estonian and five informants in Võru. The informants who use pluperfect in Estonian use it also in Võru.

Lindsröm and Toomet (2000) analysed 26 oral narratives in Estonian and found that present verbs were used $40 \%$ and past verbs $60 \%$ of the times. Their findings do not coincide with the present results. In the bilingual narratives discussed in the current study, the ratio of present verbs to past verbs in both Estonian and Võru is 30\% to $70 \%$.

Conclusion. The present and the preterite are the main grammatical tenses used both in Estonian and Võru. The perfect and the pluperfect are used seldom. The informants use more present and preterite verbs (in five and eight narratives respectively) in their Võru narratives. In both Estonian and Võru narratives, present verbs were used 30\% and past verbs $70 \%$ of the times.

\subsection{Present contexts and narrative tenses}

In the studied narratives there are eight contexts where present verbs occur (see Table 5). One of these contexts is the indirect speech, which is used to convey words of others and the narrator's reflections on or evaluations of the narrative events. However, the discussion of this 
particular present context is excluded from the current paper, as the tense choice for the indirect speech in an oral narrative conforms to a specific set of rules (grammatical hypotheses by Comrie 1986, Abusch 1988, and Declerck 1990; the hypothesis of deictic duality by Vandelanotte 2005 and Davids and Vandelanotte 2011) not relevant to the current study. Therefore the list of the present contexts below is based on the occurrence of the DP and the CHP identified in the narratives (see Table 3) and present verbs in indirect speech like contexts are not presented here.

Table 3. The deictic present and the conversational historical present in the narratives

\begin{tabular}{c|r|r|r|r|r|r|r|r}
\multirow{2}{*}{$\begin{array}{c}\text { infor- } \\
\text { mants }\end{array}$} & \multicolumn{4}{|c|}{ Estonian } & \multicolumn{4}{|c}{ Võru } \\
\cline { 2 - 9 } & words & present & $\begin{array}{c}\text { in ind } \\
\text { speeh }\end{array}$ & $\begin{array}{c}\text { DP and } \\
\text { CHP }\end{array}$ & words & present & $\begin{array}{c}\text { in ind } \\
\text { speeh }\end{array}$ & $\begin{array}{c}\text { DP and } \\
\text { CHP }\end{array}$ \\
\hline F1 & 607 & 7 & 4 & 3 & 931 & 47 & 40 & 7 \\
\hline F2 & 553 & 39 & 12 & 27 & 438 & 19 & 16 & 3 \\
\hline F3 & 954 & 54 & 23 & 31 & 1698 & 87 & 45 & 42 \\
\hline F4 & 438 & 26 & 16 & 10 & 340 & 8 & 8 & 0 \\
\hline F5 & 610 & 21 & 7 & 14 & 716 & 41 & 23 & 18 \\
\hline M1 & 1324 & 41 & 26 & 15 & 1611 & 68 & 27 & 41 \\
\hline M2 & 386 & 30 & 10 & 20 & 356 & 6 & 5 & 1 \\
\hline M3 & 466 & 26 & 14 & 12 & 238 & 13 & 12 & 1 \\
\hline M4 & 692 & 15 & 0 & 15 & 755 & 28 & 1 & 27 \\
\hline M5 & 496 & 10 & 5 & 5 & 524 & 22 & 7 & 15
\end{tabular}

The main purpose of the introduction and conclusion is to signal the deictic shift from narrating time to narrative time or vice versa. It is achieved by using the DP. For presenting the background information in the introduction and giving last-minute evaluations in the conclusion the narrative past is used. Therefore, in introductions and conclusions the present and the preterite verbs are often used intermittently, as in $(1 \mathrm{Et})$ and $(2 \mathrm{Võ})^{1}$.

1 Et - the example is in Estonian; Võ - the example is in Vorru 
(1 Et) 'aga hea lugu vä (.) aa üks hea lugu oli üks kihvt karjapäev ma arvan (.) jaa ma räägingi ühe hea loo ka (.) üks ma käisin lapsena väiksena karjas'

'A good story? OK, one good story was about a cool day herding, I guess. Yes, I am going to tell a good story as well. I went herding when I was a child.'

(2 Võ) 'et tuu olí uvitav jah (.) et ma mõtli et mille et (.) me põhjamaalase kipume ju väega nigu (.) suitsidaalse olema aga (.) aga kuis noil siis tuu asi nii ull om et (.) umetigi lämmi ja meri ja kõik ja (.) aga jah et säänne kogemus siis (.) et ei mõistaki muud et (.) hää et nii läits' 'That was interesting indeed. I thought why. We, northerners, tend to be very suicidal, but why it is so bad with them? It is warm there and they have the sea and everything. But yes, the experience is as it is. I do not know what else to say; only that it is good that it was not any worse.'

Reporting verbs are verbs of saying (e.g. tell, say, speak), perception (e.g. think, see, guess) and emotion (e.g. dread, cheer) that introduce the indirect speech. Reporting verbs can appear both in the present and preterite. However, only reporting verbs in the present are studied closer here. Reporting verbs in the DP often signal the deictic shift from narrative time to narrating time and are followed by narrator's reflections, evaluations or comments, as in (3 Et).

(3 Et) 'ma oletan et ta oli küllalt harimatu'

'I assume that he was rather uneducated.'

Asides (universal truths, descriptions of the present situation caused by past events and comments to the listener without the direct address) are discussed together as these contexts are rather difficult to tell apart. In all cases, the narrator uses the DP to signal a short deictic shift to explain the background details of or offer an evaluative insight to the narrative events, as in (4 Võ), (5 Võ) and (6 Võ $)^{2}$.

(4 Võ) 'aga siis ma nigu silma valla sai ma kai tuu akna poole ja seal olĺ iks pümme ja iks pümme ja (.) augustikuu lõpp omgi ikka ü̈̈ om joba pikk (.) otsa ta ei saa (.) ja siis ma mäleta tuud kuis (.) kuis mul nakas tuu mõte tulema et huvitav kas üü ütskõrd otsa ka saa'

2 Asides and addresses to the listener are indicated in italics in the examples. 
'As soon as I was able to open my eyes, I peeked at the window and it was dark outside. The night in August $\underline{\text { is }}$ really $\underline{\text { is }}$ long already and it does not end. And then I remember how I thought whether the night would end at all.'

(5 Võ) 'ja no siis ma kõiki saigi too asja är kõnõlda (.) aga mis (.) mis $\underline{\text { om }}$ trahv ingliskeelen tuud ma ei tia täämbatse päevani aga (.) aga kõik lätś kõrda (.) tuu (.) tuu asi jutti saia'

'And I was able to manage this thing. How $\underline{\text { is }}$ 'fine' in English I do not $\underline{\text { know }}$ also today. However, everything went well and this thing was managed with.'

(6 Võ) 'siis (.) meil om nii et et et mu emapoolne suguvõsa tuu om (.) sääne oige suur suguvõsa'

'The case with my maternal family $\underline{\text { is }}$ that it $\underline{\boldsymbol{i}}$ rather a big family.'

In addresses to the listener the DP is used. Addresses to the listener are different form asides as the deictic shift is extremely short. Also, the address to the listener is very clear, as in $(7 \mathrm{Et})$.

(7 Et) 'no $\underline{\text { kuule }}$ ma ei pidand mingit piimamannergut tassima seal selga pooleks tõmbama'

' Come on, I did not have to carry a huge milk can there and hurt my back.'

For the future, the present verb is used to express the future meaning as in (8 Võ).

(8 Et) 'ja ma ole toda oma edimese latse luku mõnõlõ iks kõnõlnu ja tõnõkõrd isski üliõpilastele kõnõlnu selle mõttega et äkki neil on kunagi kasu tuust loost aga võru keelen ma toda luku kõnõlnu ei ole ja (.) ma esi mõtli ka täitsa huviga et ku ma nä nüüd edimest kõrda tuud luku kõva häälega välja ütlema nakka et mis tunne tuu hindal või olla kui esi kuulet kuis sa tuud luku kõnõlõd'

'I have told that story of my first child to some people. I have told it sometimes even to my students with the idea that maybe they can use that story some time in the future. I have not told that story in Võru and I eagerly thought to myself that when I start telling that story out loud, what feeling I have when you hear yourself how you tell that story.'

The CHP switch is a non-compulsory feature of conversational narratives that is used to make present verbs alternate with preterite verbs to convey the episodic nature of a narrative scene. The exist- 
ence of a CHP switch usually requires characters and their interaction. Switches occur in the part of a narrative where narrative events are described. There are two types of CHP switch: the CHP-past-CHP and the past-CHP-past switches. The use of the DP in (9 Et) signals the moment when the narrator starts describing the narrative events.

(9 Et) (A) 'mina lähen perearsti juurde ja (.) perearst ee (.) kaeban talle oma ädasid ja perearst $\underline{\text { ütleb }}$ et ei see äda pole muudkui et närvid on läbi (.) (B) tegi tähtsa testi ka (.) ma õhtul kaks tundi täitsin (.) kirjutasin igasuguseid asju (.) (C) tema vaatab et ja-jaah et nii ongi (.) piisavalt palju punkte et depressioon mis depressioon (.) (D) ja kirjutas mulle paki (.) dep antidepressante (.) ütles et maru ääd et ee (.) $\mathrm{mm}$ (.) niukesed (.) uusimad (.) väljalasked (.) et (.) no et ühesõnaga pidid väga hästi mõjuma'

(A) 'I go to the GP's and complain of my problems. The GP savs that this problem is because your nerves are shot. (B) She gave an important questionnaire to fill in as well. I filled it in for two hours in the evening and wrote all kinds of things. (C) She sees that yes, this is indeed the case; there's enough points - depression is the problem. (D) She prescribed anti-depressants and said that these are really good, the latest generation. In a word, these were supposed to be very effective.'

The scene in $(9 \mathrm{Et})$ comprises of four episodes. The two episodes (A and C) where the CHP is used happen in the GP's office and describe the main narrative events. The two episodes (B and D) where preterite is used convey a different setting. The tense alternations signal the episode beginnings within the scene, foreground important narrative events and interaction with a narrative character. The preterite is used for details and background information.

The narrative tenses used in the narratives are the DP, the CHP and the narrative past. The DP signals shorter or longer deictic shifts from narrating time to narrative time or vice versa. When it appears alternately with the narrative past, its role is to describe important narrative details. The CHP signals the beginning of the narrative events and marks episodes within the narrative scene. The narrative past describes narrative events. When it appears alternately with the DP or CHP, it is used to set less important narrative details in the background (see Table 4). 
Table 4. Roles and functions of narrative tenses

\begin{tabular}{l|l|l} 
Present & Past & Past when alternating with Present \\
\hline - deictic shifts (DP) & - narrative & - narrative details and background \\
- narrative events & events & - backgrounding \\
(CHP) & & \\
- narrative details & & \\
$\begin{array}{l}\text { in the form of } \\
\text { commentaries and } \\
\text { explanations }\end{array}$ & & \\
- foregrounding & &
\end{tabular}

Conclusion. Based on the analysed narratives, there are eight contexts where present verbs are used: introductions, conclusions, reporting verbs, asides (universal truths, descriptions of the present situation and comments to the listener), addresses to the listener, the future meaning, the CHP switches and the indirect speech (not discussed in the present paper). In introductions, conclusions, reporting verbs, asides, addresses and asides the DP is used. In CHP switches the CHP is used. The role of the DP is to signal deictic shifts. Narrative events are described using mainly the narrative past. Alternate use of the narrative past and the CHP or DP is used to foreground and background information and signal episode beginnings in a narrative scene.

\subsection{Present contexts in Estonian and Võru}

As there are more preterite verbs in the Vorru narratives, it is appropriate to assume that in many contexts where in the Estonian narratives present verbs are used, in the Vorru narratives these are substituted with past verbs. What are then the "critical" contexts in Vorru where the use of present verbs is mandatory (see Table 5)? In the following examples, the contexts in Estonian and Vorru are presented together to demonstrate the differences in presentation of the same or similar information in the same narrative part. 
Table 5. Different present contexts in the bilingual oral narratives

\begin{tabular}{|c|c|c|c|c|c|c|c|c|c|c|c|c|c|c|}
\hline \multirow{2}{*}{$\begin{array}{l}\text { infor- } \\
\text { mants }\end{array}$} & \multicolumn{7}{|c|}{ Est } & \multicolumn{7}{|c|}{ Võ } \\
\hline & 1 & 2 & 3 & 4 & 5 & 6 & 7 & 1 & 2 & 3 & 4 & 5 & 6 & 7 \\
\hline 51 & $\mathrm{X}$ & 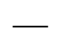 & 2 & 20 & 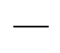 & 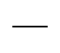 & - & $\mathrm{X}$ & - & $\lambda$ & $\Lambda$ & - & - & - \\
\hline $\mathrm{F} 2$ & $X$ & - & $X$ & - & - & - & $\mathrm{X}$ & $\mathrm{X}$ & $\mathrm{X}$ & $X$ & - & - & - & - \\
\hline $\mathrm{F} 3$ & $X$ & $X$ & $X$ & $X$ & - & $\mathrm{X}$ & - & $\mathrm{X}$ & $\mathrm{X}$ & $\mathrm{X}$ & $\mathrm{X}$ & - & $\mathrm{X}$ & - \\
\hline $\mathrm{F} 4$ & $\mathrm{X}$ & $\mathrm{X}$ & $\mathrm{X}$ & - & - & - & $\mathrm{X}$ & - & - & - & - & - & - & - \\
\hline F5 & $\mathrm{X}$ & - & 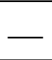 & $\mathrm{X}$ & $\mathrm{X}$ & - & $\mathrm{X}$ & $\mathrm{X}$ & $\mathrm{X}$ & $\mathrm{X}$ & $\mathrm{X}$ & - & - & - \\
\hline $\mathrm{M}$ & - & - & $\pi$ & $\mathrm{X}$ & - & - & - & $\mathrm{X}$ & 2 & $\Lambda$ & $\kappa$ & - & - & - \\
\hline $\mathrm{M}$ & $\mathrm{X}$ & - & - & $\mathrm{X}$ & - & - & - & $\mathrm{X}$ & $\mathrm{X}$ & - & - & - & - & - \\
\hline $\mathrm{M}$ & $\mathrm{X}$ & $\mathrm{X}$ & $\mathrm{X}$ & $\mathrm{X}$ & - & - & - & - & $\mathrm{X}$ & - & - & - & - & - \\
\hline $\mathrm{M}$ & $\mathrm{X}$ & - & $X$ & $\mathrm{X}$ & - & - & - & $\mathrm{X}$ & $\mathrm{X}$ & $\mathrm{X}$ & $\mathrm{X}$ & - & - & - \\
\hline M5 & 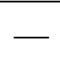 & $\mathrm{X}$ & $\mathrm{X}$ & $X$ & - & - & - & $\mathrm{X}$ & - & $\mathrm{X}$ & - & - & - & - \\
\hline
\end{tabular}

1 -introduction; 2 - conclusion; 3 -reporting verbs; 4 -asides; 5 -addressing the listener; 6 - the future meaning; 7 - the CHP switch; X-used; - - not used

The introduction is one of the most frequent present contexts in both Estonian and Võru narratives. However, not all Võru introductions feature present verbs. There are occasions when no verbs are used, as in (10), or the whole introduction is in the past, as in (11).

$$
\begin{aligned}
& \text { 'no see on tore lugu' 'nu vat' } \\
& \text { 'this is a fun story' 'well' }
\end{aligned}
$$

(11) 'kaks keelelugu võiks olla

(.) esimene lugu (.) oleks

(.) ee (.) kui pealkirja panna

siis (..) kirjutamiseusust (.)

või siis ka kirjutamiseusust ja kõnelemiseusust'

‘ja siis mul tulí (.) sis miilde üts lugu (.) umast noh (.) peris latsepõlvest et (.) kui mul olí ka joba see kirutamiseusk ja kõik selge et (.) mul olí lugemine ja kirotamine selge (.) arvatavast (.) ma käve joba koolin mähendsgi (.) edimesen tõsõn klassin ja et (.) kuimuudu (.) meil sääl koton murupääl üts (.) külämiis sähäne (.) kes arvada et esi väega vähe mõistse (.) või kellel väega vähe olí erun elun kirut (.) kuis täl kirutamise usk oll' 
'There could be two stories about language. The first one would be, if I want to give it a title, about the belief in writing, or the belief in writing and speaking.'
'I remembered a story from my childhood when I already had this belief in writing. I knew how to read and write. I was probably at school for the first or second year. At our home, on the grass, there was a man from the village who probably did not know (how to write) or wrote very little in his life, but he had belief in writing.'

In most cases, the present and the preterite verbs are used alternately as other present contexts may be embedded in the introduction. In (12), two more present contexts are embedded in the introduction: the reporting verb and the universal truth, both of which use the DP.

'mul on meeles et kui ma (.) väikene olin siis ma käisin tihti (.) heki taga (.) seal oli meil kuustik (.) ja selle ee (.) kuustiku juurest siis vaatasin maailma (.) ja (.) paistis kätte tee (.) üle järve'

'I remember that when I was small, I often went behind the hedge. We had a spruce forest there. At this spruce forest I looked out into the world and saw the road across the lake.' 'ma oli (.) külaltki väikene (.) mõista-i joht üelda kui vana just (.) aga kindlale veel koolih es käü (.) ja (..) olli kodo man mähänä kuusistik (.) ja kuusistiku pealt paistuś suurtii (.) no suurtii pääle no sinna jääs vast umbes nii (.) puul kilomeetrit (.) massina sõitva'

'I was rather small. I do not know how old but surely I did not go to school yet. Near my home there was a spruce forest and at this forest the road was visible. It is approximately half a kilometre to the road. The vehicles drive (on the road).'

Not all narratives have a clear conclusion. Sometimes conclusive evaluative remarks are hidden in the description of narrative events and the narrative itself ends abruptly. In the analysed narratives, there is a slight tendency to use more present verbs in the Võru conclusions than in the Estonian conclusions. Four types of conclusions were noted in the Vorru narratives: 1. The informant uses no verb, as in (13); 2. Only present verbs are used, as in (14); 3. Only past verbs are used, as in (15); 4. Present and past verbs are used intermittently, as in (16). 
(13) ‘ja siis ma mõtlesin et on parem konjakki või eetrit võtta nii palju kui vaja on (.) aga siis $\underline{\mathbf{s a a b}}$ vähemalt joobeastme (.) aga toda pohmelli enne 'vot niisukene lugu (.) pole küll niiviisi vaja et (.) et see on minu ainuke kogemus antidepressandiga (.) ja rohkem ma ei võtnud (.) vot'

'I thought that it is better to drink cognac or ether as much as necessary because it makes drunk. Hangover without being drunk is completely 'That (is) the story with antidepressants.' unnecessary. This is my only experience with antidepressants. I did not take them anymore and that's it.'

'et aga (.) aga see lugu on väga oluline mu jaoks (.) ja ma arvan et ta tõesti määras mu suhtumise (.) pereellu lastesse (.) kõigesse ümbritsevasse (.) ja tõesti seda kõige pikemat ööd mida ma oma elust mäletan (.) kuidas ma ootasin valgust (.)et ma ei tea kas ma kunagi veel midagi nii (.) nii hullupööra oodanud olen (.) see oligi lugu'

'This story is very important to me. I think it defined my attitude to family life, to children, to everything around me. I really remember the longest night of my life, how I waited for light. I do not know whether I ever have waited anything so much. That was the story.' 'aga ega ma rohkemp ei mõistagi tuu loo kohta nüid (.) sää tuu tuu oma edimesen keelen üteldä et ee (.) nii nigu üteldasse et ega lugu piassi õige mitu kõrda kõnõlõma (.) et tuu kõgõ õigemb vorm kätte tule (.) et sjoo edimene variant (.) noh om nagu ta om sis'

'I do not know what else to say about this story in my first language. As it is said, a story needs to be told several times and then it takes the correct form. The first version is as it is.' 
(15) 'aga selle asja peale tulin ma märgatavalt hiljem (.) kui ma kunagi sealt jala läbi kõmpisin (.) ja äkitselt taipasin oma vanale probleemile (.) vastuse leida'

'I realised this much later when I went through this place on foot and suddenly found a solution to my old problem.'

(16) 'a mu arvost olí tuu (.) õige mitu aastat ildampa (.) kui ma äkki taibasi (.) vahepeal uneti tuu mure ärrki joba'

'It was some years later when I realised (what the problem was). I had forgotten all about it meanwhile.' 'aga tal oli väga hea tunne väga hea meel (.) tema sai oma tahtmise rikkus mu hobuseratsutamise ära lehmaratsutamise ära (.) vot pärast saime veel sõimata kah lauda juures et lehmad kaks tundi varem koju said kuidagimoodi'

'She was very happy. She got what she wanted. She ruined my riding on the horse, on the cow. Later we were told off at the barn because the cows got home two hours earlier.' ‘ja tal olí hää miil (.) ja kui me kodo viil lehmiga saimi (.) saimi viil sõimada kah et mille lehmä nii vara kodo saivõ (.) tuud ma inämp ei mäleta kas me pidime karaga tagasi minemä või mitte (.) aga sõimata me saimi ja süüdi jäi iks ma' sest ta olí brigadiri tütär (.) ma olí va liht lüpsjä tütär mõttetu mutt vot'

'She was happy. When we got home with the cows, we were told off because the cows got home too early. I cannot remember whether we had to go back with the herd or not, but we were told off and I was the guilty one, because she was the foreman's daughter and I was only a milkmaid's daughter, not very important at all.'

Reporting verbs constitute another frequent present context in oral narratives. Only two informants used present reporting verbs neither in Estonian nor in Võru. Others used them in both narratives, as in (17), or at least in one narrative.

'kui ma nüüd praegu täiskasvanuna $\underline{\text { mõtlen }}$ et (.) ega need koerad minu vastu ilmselt huvi ei tundnudki (.) et nad tundsid Tipa vastu huvi'

'Now, as an adult, I think that these dogs were probably not interested in me, they were interested in Tipa.' 'no nüid ma tiä, et et Tipal oll (.) jooksuaig'

'Now I know that Tipa was in heat.' 
Asides (universal truths, descriptions of the present moment and comments to the listener) are the contexts that occur mostly in Estonian narratives. However, the informants who use asides in Estonian use them also in Võru, as in (18).

‘ja siis söödi seda (.) Euphorbia
Canariensist sisse (.) sö̈ödi
seda kitsejuustu ja mingi siukse
asjaga et (.) teda on (.) päris
vastik omastada sest ta on siuke
(.) kibe ja lónikab kohe ja (.)
nagu ma ütlesin mul oli kohe
kurgus siuke terav valu’

'Euphorbia Canariensis was eaten. It was eaten with goat cheese or something like that. It $\underline{\text { is }}$ difficult to eat because it

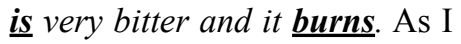
said I had this sharp pain in my throat.' 'tuu om sääne nigu (.) nigu fetajuustu mundu veidükene aga (.) ta ei ole nigu (.) tollen suhten juustukera midä lóigata aga tuu om sääne (.) puulvetel mögin vä (.) noh leiva pääle määri säänne (.) et siis na olliva võtnu kitsejuustu (.) koopale'

'It is like feta cheese. It $\underline{\text { is }}$ not like a ball of cheese that can be cut. It $\underline{\text { is }}$ kind of semi-liquid mass that can be spread on the slice of bread. So, they had taken this goat cheese to the cave.'

Addressing the listener and expressing a future meaning using present verbs are rare contexts. Addressing the listener appears in one Estonian narrative, as in $(7 \mathrm{Et})$, and using present verbs to express a future meaning appears in one narrative pair, but in different parts of the narrative, as in $(8 \mathrm{Et})$ and $(19 \mathrm{Et})$.

(19 Et) 'see oleks võinud olla öö mille tagajärjel kõik mu tulevased lapsed sündimata jäävad'

'It could have been a night because of which all my future children remain unborn.'

The CHP switches are used only in Estonian and not in Vorru. With asides, CHP switches relay the narrative events of the Estonian narratives using present verbs, while the same or similar information in the Võru narratives is conveyed by preterite verbs, as in (20). 
(20) 'see oli nüüd natukene nagu selline tausta rääkimine (.) noh ja siis (.) sellel ilusal hommikul lähen mina kooli ja (.) tavaliselt ikka läksime vennaga koos aga (.) siis jäi vend nagu maha ütles et oot-oot (..) akka nüüd ees minema et (.) küll ma tulen järgi kohe (.) saan mina juba läbi metsa ära ja jõuan juba põllule ja (.) ikka kogu aeg vahin selja taha - venda ei ole (.) ja siis $\underline{\text { tuleb }}$ nii et kuulen tõesti et põõsad ragisevad suure jooksuga mu vend ja (.) jookseb mulle järgi ja paneb mulle kirja pihku ja ütleb et (.) enne lugeda ei tohi kui saad sinna maanteele mis koolimaja juurde läheb (.) ja kui loed siis saad peksa (.) ütles mulle kohe nii (.) ta oli must aastakese vanem ka või poolteist (.) noh (..) mis siis ikka (.) küll ma oleks tahtnud varem ka lugeda (.) ja ise pööras tagasi ja läks nagu ära (.) ja oleks tahtnud nagu varem ka lugeda aga ikkagi ei julgenud ka et äkki (.) kuskilt puu tagant piilub või põõsa tagant ja (.) ja siis kui jõudsin maanteele siis (..) loen seda kirja (.) ütle õpetajale et ma olen haige (.) aga ma lähen kalale' 'tavaliselt kävvi me velega üten aga (.) tä tuukõrd jäi minust nagu maha ja (.) ma lätsi ütsinda iin minemä (.) äkki koskil keset põldu jõudse ta mulle järgi küll ja (.) joos suure joosuga tulí ja pistse mulle midagi peio ja (.) juuskse esi takasi (.) esi üteí viil (.) üle ola et (.) et sa ei tohi inne lukõ ku jõuvat sinna suurõ tii pääle et (.) sääl võit seä kirja lukõ ja (.) ja (.) kellel ja ku sa inne loet et siis võit mu käest kere pääle ka saia (.) ma muidugi (..) poiskõse asi eks ma mõtli ka et võibolla and ka kere pale (.) kuigi ega me väega es kakle kui me latse ollime (.) aga noh (.) iks must paar aastat vamemb ka olí (.) no ja kui ma siis suure tii pääle jõudse siis ma tegi kirä vallale ja (.) loi et (.) sa ei või õpetajale ütleda et (.) ma täämbä kuuli ei tulõ (.) ee (.) või õigõmbahe et ma ole täämbä haige (.) et sa peat nii ütlemä (.) aga (.) ee et kindlahe et sa midagi muut ei kõnõlõ (.) ja toost kiräst är ei tohi sa kellelegi midägi kõnõlda' 
'This was telling the background. And then in this beautiful morning I go to school. We went usually together, me and my brother. This time, however, my brother remained behind and said that go ahead, I will follow soon. I go through the forest and get to the field and all the time I look back brother is not there. And then he comes, and I hear how bushes crack, and runs after me. He gives me a letter and says that do not read before you get to the highway that goes to the school and if you read before that, I will beat you up. This was what he said to me. He was a year or so older than me. So, that's it. I would have liked to read the letter earlier. Brother turned around and seemed to go away. I would have liked to read earlier but I did not dear to. Maybe he peeks from behind a tree or a bush. When I got to the highway, I read the letter: tell the teacher I am ill, but actually I went fishing.'
'We usually went together (to school) with brother but this time he remained behind. I went ahead alone. Suddenly somewhere in the middle of the field he caught me. He ran, came running and gave me something and ran back. He said over his shoulder that you mustn't read it before you get to the highway. Only when there you can read this letter and if you read it earlier, I might beat you up. Of course, he was a little boy but I thought that he might beat me up. We did not fight very much when we were children, but he was a couple of years older than me. When I got to the highway, I opened the letter and read that you cannot tell the teacher that I will not come to school today or, to be more correct, I am ill today. This is what you need to tell the teacher but do not tell anything else. And you mustn't tell anything about this letter to anybody.'

Conclusion. In both Estonian and Võru narratives, the most frequent present contexts are the introduction, reporting verbs and the conclusion. The rarest in both narratives are addressing the listener and the future meaning. Although asides are used much in Estonian, they are not very frequent in Võru. The information expressed with asides in Estonian is often excluded in Võru. The present contexts not used in Vorru are addressing the listener and the CHP switch. Consequently, the narrative events in Võru are relayed using past verbs. 


\section{Conclusion}

The informants use mainly present and preterite verbs in their narratives. There are also instances of perfect and pluperfect verbs. The narrative tenses used are the narrative past, the DP and the CHP. The main use of the DP is to signal deictic shifts. The CHP and the narrative past are used alternately in CHP switches. The narrative present (the DP and CHP) and the narrative past are used alternately to foreground (the present verb is used) and background (the past verb is used) the information. The narrative past is used to describe narrative events.

It was possible to distinguish eight different contexts where present verbs are used: the introduction, the conclusion, reporting verbs, asides (universal truths, descriptions of the situation at the present moment and comments to the listener), addressing the listener, the future meaning, the conversational historical present switch and the indirect speech. The indirect speech is excluded from the present analysis as it is difficult, if not impossible, to determine which of the narrative tenses is used, as in the indirect speech several deictic anchor points are used.

Almost all narratives feature present verbs in the introduction and in reporting verbs. Asides are more frequent in the Estonian narratives than they are in the Vorru narratives. There is only one instance of present verb use for future reference and for addressing the listener each. Also the CHP switch is not very common: it does not occur in the Võru narratives and is used by three informants. The present contexts that are used much in the Vorru narratives are the introduction, the conclusion and reporting verbs. In other contexts (asides, addressing the listener, the future meaning and the CHP switch), the information is either excluded or substituted with something else or the information is conveyed using preterite verbs. It seems that, based on the current data, informants favour more present verbs when relating narrative events in Estonian. However, in Võru the narrative events are related using mostly preterite verbs.

\section{Address:}

Liina Tammekänd

Eesti ja üldkeeleteaduse instituut

Tartu Ülikool

Ülikooli 18

50090 Tartu, Eesti

E-mail: liina.tammekand@ut.ee 


\section{References}

Abusch, Dorit (1988) "Sequence of tense, intentionality, and scope". In Hagit Borer The proceedings of the 7th West Coast conference on formal linguistics, 1-14. The Stanford Linguistics Association.

Bonilla, Carrie (2011) "The conservational historical present in oral Spanish narratives". Hispania 94, 3, 429-442.

Carter, Ronald and Michael McCarthy (2006) Cambridge grammar of English. Cambridge: Cambridge University Press.

Comrie, Bernard (1986) “Tense in indirect speech”. Folia Linguistica 20, 3-4, 65-96.

Davidse, Kristin and Lieven Vandelanotte (2011) "Tense use in direct and indirect speech in English". Journal of Pragmatics 43, 1, 236-250.

Declerck, Renaat (1990) "Sequence of tenses in English". Folia Linguistica 24, 513-544.

EKG I = Erelt, Mati, Tiiu Erelt, Ülle Viks, Reet Kasik, Helle Metslang, Henno Rajandi, Kristiina Ross, Henn Saari, Kaja Tael, and Silvi Vare (1995) Eesti keele grammatika I. Morfoloogia sõnamoodustus. Tallinn: Eesti Keele Instiuut.

EKG II = Erelt, Mati, Tiiu Erelt, Ülle Viks, Reet Kasik, Helle Metslang, Henno Rajandi, Kristiina Ross, Henn Saari, Kaja Tael, Silvi Vare (1993) Eesti keele grammatika II. Süntaks. Tallinn: Eesti Keele Instiuut.

Erelt, Mati (2013) Eesti keele lauseõpetus. Sissejuhatus. Öeldis. Tartu: University of Tartu.

Fludernik, Monika (1991) "The historical present tense yet again. Tense switching and narrative dynamics in oral and quasi-oral storytelling". Text 11, 365-398.

Fludernik, Monika (2003) "Chronology, time, tense and experientiality in narrative". Language and Literature 12, 2, 117-134.

Fludernik, Monika (2009) An introduction into narratology. London: Routledge.

Genette, Gerard (1972) Discourse du récit. Editions due Seuil.

Hamburger, Käte ([1955] 2011) “The timelessness of poetry.” In Jan Christoph Meister and Wilhelm Schernus Time: from concept to narrative construct. A reader 85-108. Berlin: de Gruyter.

Jahn, Manfred (2005) A guide to narratology. Available at $<\mathrm{http}$ ://www.uni-koeln.de/ ame02/pppn.htm>. Accessed on 16.08.2015.

Lindström, Liina and Piret Toomet (2000) "Eesti suuliste narratiivide keelelisi erijooni". In Tiit Hennoste Eesti keele allkeeled, 174-203. Tartu: Tartu Ülikooli Kirjastus.

Nara, Hiroshi (2011) "Aspect and discourse in tense-switching: a case study of Natsume Sōseki's 'Botchan'”. Japanese Language and Literature 45, 1, 273-305.

Sakita, Tomoko (2002) Reporting discourse, tense and cognition. Amsterdam: Elsevier. Schriffin, Deborah (1981) "Tense variation in narrative". Language 57, 1, 45-62.

Silva-Corvalán, Carmen (1983) "Tense and aspect in oral Spanish narrative: context and meaning”. Language 59, 4, 760-780. 
Vandelanotte, Lieven (2005) "Tense in indirect speech and thought: some proposed modifications". In Bart Hollebrandse, Angeliek van Hout and Co Vet Crosslinguistic views on tense, aspect and modality, 61-75. Amsterdam and New York: Rodopi.

Wolfson, Nessa (1978) "A feature of performed narrative: the conversational historical present". Language in Society 7, 2, 215-237.

Wolfson, Nessa (1979) "The conversational historical present alternation". Language $55,1,168-182$.

Wolfson, Nessa (1989) “The conversational historical present”. Linx 20, 135-151.

Kokkuvõte. Liina Tammekänd: Olevikuverbid ja nende kontekstid kakskeelsetes suulistes narratiivides. Artiklis käsitletakse olevikuverbide esinemist kümnes eesti-võru narratiivipaaris. Uurimisküsimusteks on: milliseid narratiiviaegu leiab eesti ja võru narratiividest ja millised on nende rollid, millistes narratiiviosades olevikuverbe kasutatakse ja milliseid olevikukontekste võru narratiividest leiab. Ilmnes, et suulistes narratiivides kasutatakse deiktilist minevikku, deiktilist olevikku ja konversatsioonilist ajaloolist olevikku kaheksas kontekstis: sissjuhatus, kokkuvõte, saateverbid, kommentaarid (üldised tõed, hetkeolukorra kirjeldused, otsese pöördumiseta kommentaarid kuulajale), kuulaja poole pöördumised, tulevikuline tähendus, ümberlülitumine oleviku- ja mineviku verbide vahel ja tsitaatkõne. Võru narratiivides esines vähe või ei esinenud üldse kommentaare, kuulaja poole pöördumist ja ümberlülitumist oleviku- ja mineviku verbide vahel. Seega kasutati võru narratiivides narratiivisündmuste kirjeldamiseks võrreldes eesti narratiividega enam minevikuverbe.

Märksõnad: kakskeelne suuline narratiiv, narratiiviajad, konversatsiooniline ajalooline olevik, eesti, võru 